\title{
INVESTIGATION OF ANTINUTRITIVE COMPONENTS IN HUNGARIAN POTATO CULTIVARS DEPENDING ON PRODUCTION TECHNOLOGY
}

\author{
R. TömÖsKöZi-Farkasa ${ }^{a}$, M. Berki ${ }^{a}$, M. Nagy-Gasztonyi ${ }^{\mathrm{a}}$, I. Wolf ${ }^{\mathrm{b}}$ and Zs. Polgár ${ }^{\mathrm{b}}$ \\ ${ }^{a}$ National Agricultural Research and Innovation Centre, Food Science Research Institute, \\ H-1022 Budapest, Herman Ottó út 15. Hungary \\ ${ }^{\mathrm{b}}$ Potato Research Centre, University of Pannonia, H-8360 Keszthely, Deák F. út 16. Hungary
}

(Received: 11 April 2014; accepted: 14 July 2014)

\begin{abstract}
We have investigated the Total Glycoalcaloid (TGA), nitrite, and nitrate contents of some Hungarian and foreign potato cultivars in relation to the effect of different combination of fertilisers and green manure, late blight management strategies (none, programmed, or prediction based spraying), and irrigation regime for three years. The Hungarian cultivars have exotic potato species like S. acaule, S. demissum, S. stoloniferum, S. vernei, or S. tub. ssp. andigenum in their genetic background as sources of resistance genes. No effect of fertilisers or irrigation was found on the level of glycoalkaloids and nitrate contents, which were influenced mostly by the genotype and season. In conclusion, the absolute amount and the presence of different antinutritive components of potato tubers were influenced by the technology, genotype, and season in a complex manner. These results in general prove that ware potato production utilising intensive commercial agrotechnical practices and common cultivars is safe regarding the nitrate and TGA content of tubers.
\end{abstract}

Keywords: potato, glycoalkaloids, nitrate, production technology, HPLC

Potato is one of the most important staple foods and it plays a significant role in human diet worldwide (FAO, 2008). Its profitable cultivation assumes the operation of intensive plant nutrition, irrigation, and plant protection systems basically based on the mass use of fertilisers and plant protective chemicals. The decrease of environmental and food safety risk of intensive potato production is a major challenge for today's growers. To meet the increasing demands, the use of cultivars having wide range of adaptability to diverse environmental factors (KNUTHSEN et al., 2009; HASSANPANAH, 2010), good nitrogen use efficiency (GHOLIPOURI \& KANDI, 2012), resistance against the most important pathogens and pests (ForBES, 1999) is one of the possibilities. The other is the optimisation of nutrition and plant protection practices to the specific needs of cultivars and environmental circumstances (e.g. combination of late blight resistant cultivars with signalling based integrated plant protection technology).

From the human nutrition point of view, occurrence of several types of antinutritive components, such as steroidal glycoalkaloids, threatens consumers' health (see review by NemA and co-workers, 2008; Friedman and Levin, 2009). The glycoalkaloid content in tubers is affected by the genotype, climate, production technology, storage time, sprouting, and exposure to light and heat.

Nitrogen fertilisation can cause significant increase in nitrate and nitrite content of tubers, but the genotype and production technology may have an effect on the concentration

* To whom correspondence should be addressed.
Phone: +36-1-214-1249; fax: +36-1-214-1249; e-mail: r.farkas@cfri.hu

0239-3006/\$20.00 @ 2014 Akadémiai Kiadó, Budapest 
of these compounds (Augustin et al., 1977; Hamouz et al., 1999). Nitrogen is absorbed by plants in the form of either ammonium $\left(\mathrm{NH}_{4}{ }^{+}\right)$or nitrate $\left(\mathrm{NO}_{3}{ }^{-}\right)$, depending on the species, cultivar, age, and soil conditions (Greenwood \& Hunt, 1986; Rao \& Puttanna, 2000). Nitrate accumulation in plants is a natural phenomenon resulting from uptake of the nitrate ion in excess of its reduction and subsequent assimilation. The Expert Committee of FAO/ WHO determined the Acceptable Daily Intake (ADI) value as $5 \mathrm{mg}$ sodium nitrate and 0.2 mg sodium nitrite/body weight $\mathrm{kg}$. Consumption of high levels of nitrate may cause health problems, for example methaemoglobinaemia in babies (Rao \& Puttanna, 2000) and some types of cancer (Forman \& Doll, 1985; Mensinga et al., 2003).

The aim of the present study was to compare some pathogen resistant Hungarian potato cultivars with in general pathogen sensitive foreign ones regarding quality components of their tubers, such as steroidal glycoalkaloids, nitrate and nitrite content, grown under different farming practices (different fertiliser combinations, signalling based late blight management strategies, and irrigation system). Studying the effect of seasonal variation for 4 years was also aimed.

\section{Materials and methods}

\subsection{Plant materials and growth conditions}

Hungarian potato cultivars of University of Pannonia (Balatoni Rózsa, Rioja, Vénusz Gold, White Lady) having complex resistance to potato viruses, fungi and bacteria and pathogen susceptible foreign cultivars (Laura, Red Scarlet, Desiree, Cherie, Franceline, Natasha, Saline) were grown at two locations (Komárom and Solt, Hungary) using standard agricultural practices (tillage, $75 \mathrm{~cm}$ row and $30 \mathrm{~cm}$ within row spacing) for four years (2010-2013) in four replications (plot size $1000 \mathrm{~m}^{2}$ ). Soil quality was determined by official soil sampling. The $\mathrm{pH}$ of soils varied between 6.8-7.2.

I. Natural precipitation, no irrigation:

2010: Komárom 605 mm, Solt 416 mm (April-August)

2011: Komárom $216 \mathrm{~mm}$, Solt $170 \mathrm{~mm}$ (April-August)

2012: Komárom 139 mm, Solt 98 mm(April-August)

2013: Komárom 264 mm, Solt 303 mm (April-August)

II. Natural precipitation + irrigation:

2010: Komárom 605 mm+10+45+15 mm (May, July, August), Solt $416 \mathrm{~mm}+20 \mathrm{~mm}$ (July)

2011: Komárom 216 mm+20+45+25 mm (May, June, July),

Solt $170 \mathrm{~mm}+20+40+20 \mathrm{~mm}$ (June, July, August),

2012: Komárom 139 mm+50+20+20+20 mm (May, June, July, August), Solt $98 \mathrm{~mm}+20+40+50+75+65+20 \mathrm{~mm}$ (April, May, June, July,August, September)

2013: Komárom 264 mm+10+40+40 mm (May, July, August)

Solt $303 \mathrm{~mm}+56+106 \mathrm{~mm}$ (July, August)

Late blight control strategy:

I. None needs)

II. Programmed application (5-10 times in 6-8 days interval depending on the seasonal

III. Prognostic application (based on NoBlight computer modelling program) 
Fertilization:

MT1: $\quad$ Fertiliser $1\left(\mathrm{~N} 50+200, \mathrm{P}_{2} \mathrm{O}_{5} 150, \mathrm{~K}_{2} \mathrm{O} 300 \mathrm{~kg} \mathrm{ha}^{-1}\right)$

MT1+Z: $\quad$ Fertiliser $1+$ green manure (oil radish)

MT2: $\quad$ Fertiliser $2\left(\mathrm{~N} 100+200, \mathrm{P}_{2} \mathrm{O}_{5} 150, \mathrm{~K}_{2} \mathrm{O} 300 \mathrm{~kg} \mathrm{ha}^{-1}\right)$

MT2+Z: Fertiliser $2+$ green manure (oil radish)

\subsection{Chemicals}

The standard materials ( $\alpha$-solanine and $\alpha$-chachonine) and chemicals were purchased from Sigma-Aldrich Ltd. (St Louis, USA). Acetonitrile was purchased from Merck (Darmstadt, Germany). All reagents were of analytical reagent grade. Ultrapure water generated by the Milli-Q System (Millipore, Darmstadt, Germany) was used. SPE (Solid Phase Extraction) cartridge (ENVI-18 $6 \mathrm{ml}$ ) and PTFE (Polytetrafluorethylene) sample filter $(25 \mathrm{~mm} \times 0.45 \mu \mathrm{m})$ were purchased from Supelco Co. (St Louis, USA).

\subsection{Sampling}

After harvest, $20 \mathrm{~kg}$ of tubers from each experimental parcel representing the farming technologies were collected. For the 3 parallel measurements $3 \times 3$ tubers were selected and prepared to get homogenous samples.

\subsection{Potato processing}

Potatoes were washed, peeled ( $2 \mathrm{~mm}$ thickness), and raw tuber material was crushed by a chopper (Philips HR 1392). All samples were then freeze dried and subjected to further analysis. The lyophilised samples were ground to powder (Bosch MKM6003). Potato powder was stored at room temperature until the analyses were performed. The investigated components are stable at room temperature and our preliminary experiments proved that under the applied conditions the freeze drying method did not damage any of these compounds. The dry matter content was calculated from the weight of the raw and the lyophilised potato tubers.

\subsection{Chemical determinations}

1.5.1. Glycoalkaloid analysis. To concentrate the glycoalkaloids from the potato samples, solid-phase extraction (SPE) with a disposable Supelclean C18 column was used (Houben \& BRUNT, 1994).

HPLC analysis was performed using an Agilent 1200 Separation Module, consisting of an autosampler with a $20 \mu 1$ loop and an Agilent diode array detector. The data were evaluated with ChemStation Software. Agilent Eclipse XDB-C18 $4.6 \mathrm{~mm} \times 150 \mathrm{~mm} \times 5 \mu \mathrm{m}$ column was used with acetonitrile:buffer $(50: 50, \mathrm{v} / \mathrm{v})$ as the mobile phase. The buffer was prepared by dissolving $1.2 \mathrm{~g}\left(\mathrm{NH}_{4}\right)_{2} \mathrm{HPO}_{4}$ in $1000 \mathrm{ml}$ of bidistilled water. The isocratic elution was performed at flow rate of $0.5 \mathrm{ml} \mathrm{min}{ }^{-1}$. The column effluent was monitored at $202 \mathrm{~nm}$ and $20 \mu \mathrm{l}$ were injected (TöмÖSKÖZI-FARKAS et al., 2006).

1.5.2. Determination of nitrate and nitrite contents. Measurements of nitrate and nitrite were carried out with the standard method of AOAC (2000). $25 \mathrm{~g}$ of potato samples were shaken with water for $15 \mathrm{~min}$. After shaking, $2 \mathrm{ml} \mathrm{Carrez} \mathrm{I} \mathrm{and} 2 \mathrm{ml}$ Carrez II solutions were 
added to precipitate proteins, it was made up to $50 \mathrm{ml}$ and filtered. From the filtrate, $5 \mathrm{ml}$ was mixed with $5 \mathrm{ml}$ Griess solution. After allowing to stand for $15 \mathrm{~min}$, the absorbance of the samples was measured against sample blank at $530 \mathrm{~nm}$. To determine nitrite concentration, $0.5 \mathrm{ml}$ of the filtrate was completed to $10 \mathrm{ml}$ with water. Two $\mathrm{ml}$ ammonium solution $(25 \%)$ and $500 \mathrm{mg}$ zinc powder were added. One $\mathrm{ml}$ of cadmium-acetate solution was injected and was allowed to stand for $5 \mathrm{~min}$ without moving. The solution was shaken slowly for $15 \mathrm{~min}$, then it was completed to $50 \mathrm{ml}$ with water and filtered. From this filtrate, $5 \mathrm{ml}$ was mixed with $5 \mathrm{ml}$ Griess solution. After allowing to stand for $15 \mathrm{~min}$, the absorbance of the samples was measured against sample blank at $530 \mathrm{~nm}$.

\subsection{Statistics}

For statistical analysis of experimental two-sample $t$-probe, F-probe (Excel software) were used.

\section{Results and discussion}

\subsection{Effect of technology on glycoalkaloids}

Late blight control strategy has great importance both of economic and environmental point of view. Depending on season, 2-3 sprayings could be executed. As Table 1 shows, there were no significant differences in TGA content, regardless of applied spraying strategies, in 2011 and 2013. However, inverse effect was observed between fungicide use and TGA content in 2012 (Fig. 1). (In 2010 we could not evaluate this part of the experiment due to internal water damage of the experimental site.) Higher number of fungicide application (programmed spraying) elevated the TGA content of tubers. The highest values were measured in tubers from non-treated plots. This phenomenon could originate from the cumulated effect of biotic and abiotic stresses caused by $P$. infestans infection and the severe drought period of that year.

No correlation was observed between irrigation and TGA content of tubers (Table 2). As the statistical analysis proved, the differences were not significant and consequent. Significant difference was observed in case of Katica in 2013, but this could be originated from the inadequate storage of these samples. The same tendencies were observed this year in the fertilization experiments (Table 3). However, the average TGA content in tubers of all cultivars were lower in samples from Komárom compared to Solt. This alteration may come from the existing ecological differences of the two locations (e.g. soil type, alterations in daily temperatures, number of days with heat, or water stress, etc.).

Results regarding fertilization methods can be seen in the Table 3. No consequent tendency was observed between treatments and TGA content. Higher dose of N (Fertilizer 2, MT2+Z) resulted in a lower TGA content in Red Scarlet, Katica, Laura, Rioja, and Balatoni Rózsa in 2012, but this phenomenon was not found in 2011 and 2013. In most cases the application of green manure caused a higher TGA content, but the differences were not significant.

\subsection{Effect of technology on nitrate and nitrite content}

The effect of irrigation and fertilization was investigated on the concentration of nitrate and nitrite in tubers. 

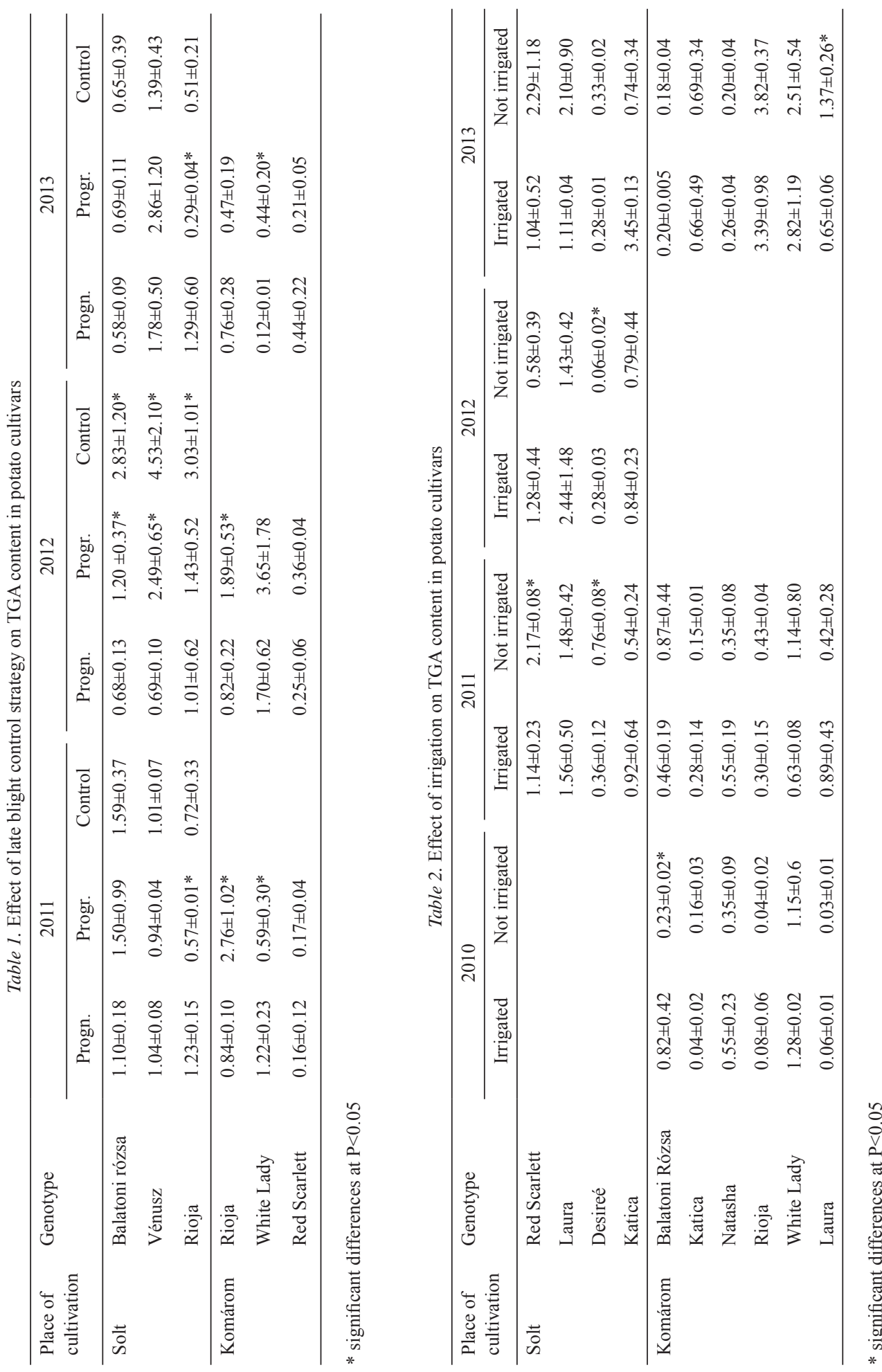
TÖMÖSKÖZI-FARKAS et al.: ANTINUTRITIVES IN POTATO AND PRODUCTION
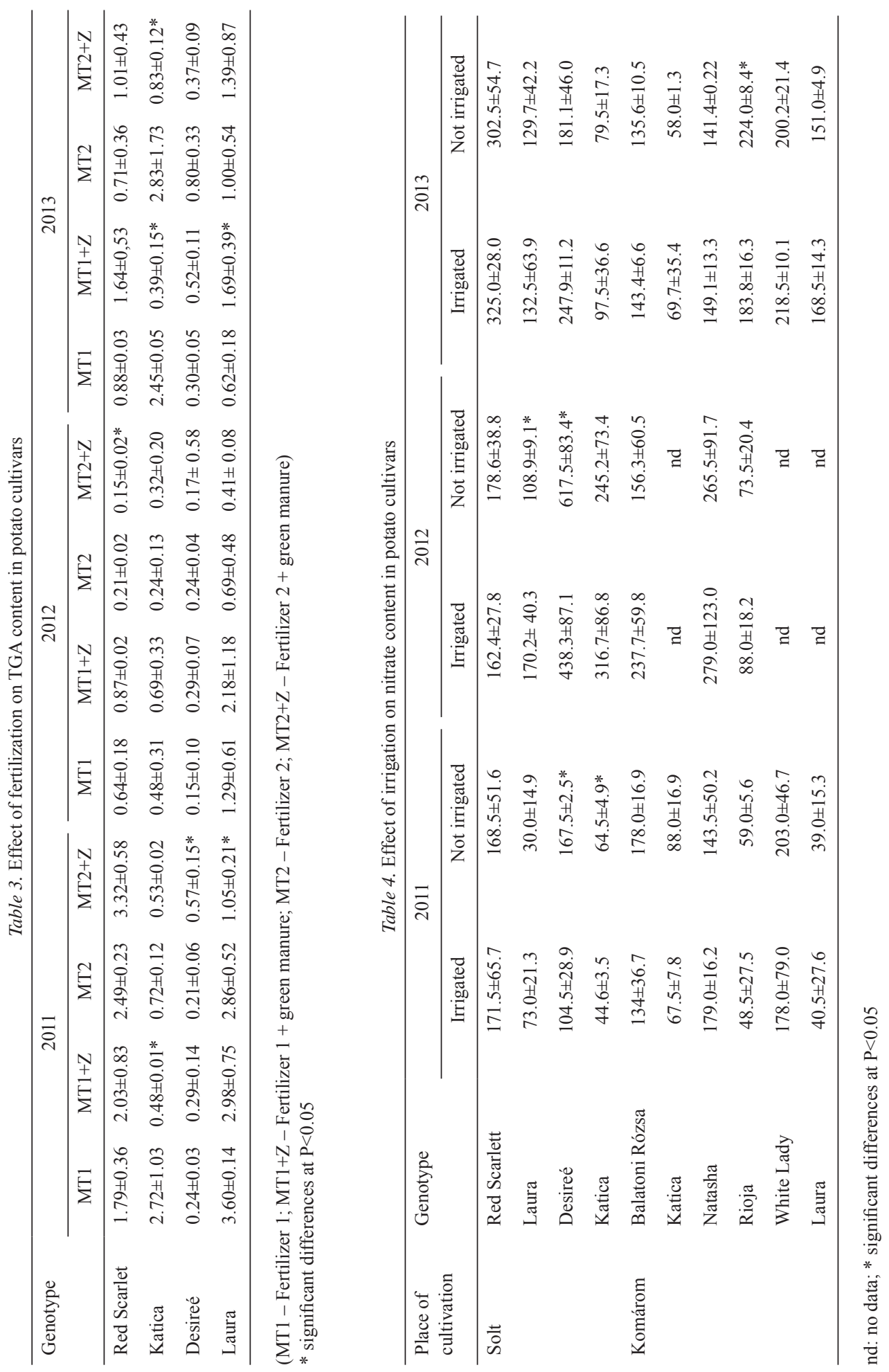


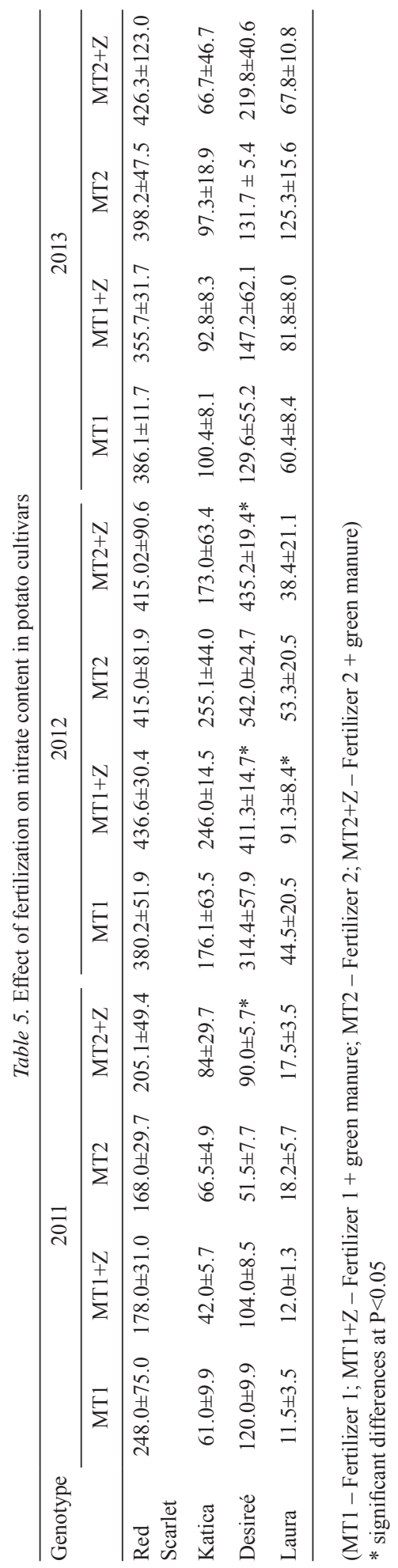




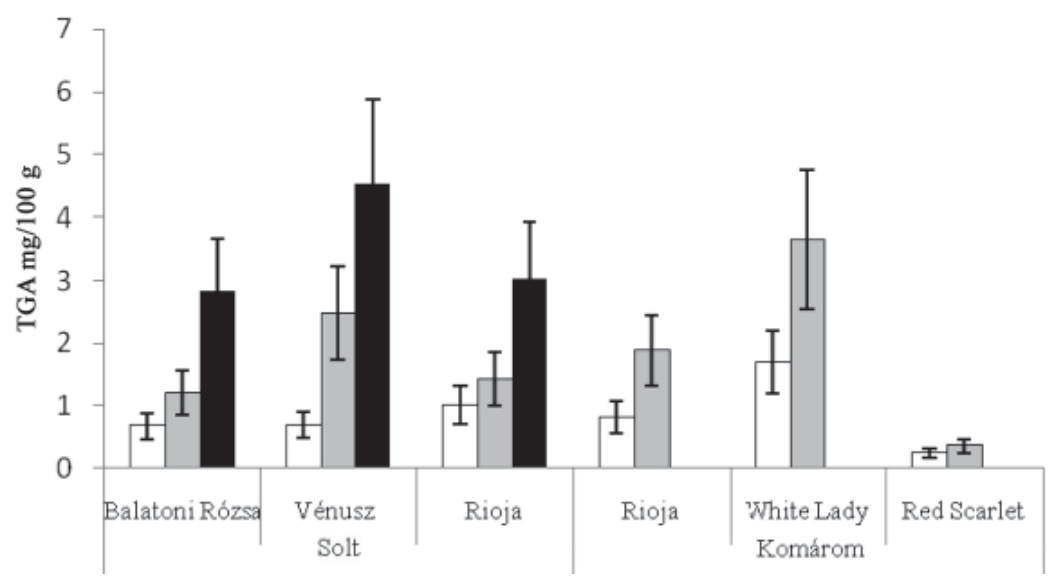

Fig. 1. Effect of late blight control strategy on TGA content in potato cultivars in 2012.

$\square$ :control; $\square$ : programmed; $\square$ : prognostic

The nitrite content of tubers was lower than $0.1 \mathrm{mg} \mathrm{kg}^{-1}$, except in a few cases, and there were no significant differences under the various circumstances (data are not shown). In most cases the irrigated samples contained higher concentration of nitrate, but the differences were not significant. The maximum levels of nitrate were found in Laura from Solt, $73 \mathrm{mg} \mathrm{kg}$ (2011), $170 \mathrm{mg} \mathrm{kg}^{-1}$ (2012), and $132 \mathrm{mg} \mathrm{kg}^{-1}$ (2013). The tendency was the same in all cultivars. Nitrate content was primarily influenced by the genotype and the season.

Results regarding fertilization methods can be seen in the Table 5. No significant difference was observed between treatments (Fertilizer 1 and 2) in the three years. The effect of green manure was observed in 2013, significantly higher concentration was measured in the cultivars Red Scarlet and Laura. The mean concentration of nitrate was two times higher in 2012 than 2011 in case of each cultivar, emphasising the stronger effect of the genotype and season.

\section{Conclusions}

Based on our results, we can state that under the examined circumstances, the genotype had the highest effect on the TGA and nitrate contents of tubers. However, the genetic determination of these parameters can be significantly modified by seasonal effects. None of the examined agrotechnical methods (different ways of fertilisation or late blight control strategies) influenced consequently and significantly the investigated antinutritive components of tubers. None of the investigated tuber values exceeded or came close to food safety standards. These results in general prove that ware potato production utilising intensive commercial agrotechnical practices and common cultivars is safe regarding the nitrate and TGA content of tubers. However, other tuber components like heavy metals and chemical residues also need to be investigated to come up with a more general statement about food safety of table potato production. 


\section{References}

AOAC (2000): Nitrate in baby foods. Spectrophotometric method; Official Method No. 993.03

Augustin, J., Mc Dole, R.E. \& Painter, G.C. (1977): Influence of fertilizer, irrigation, and storage treatments on nitrate N content of potato tubers. American Potato J., 54, 125-136.

FAO (2008): International year of the potato (2008). available at: http://www.fao.org/potato-2008/en/potato/index. html

Forbes, G.A. (1999): Genotype by environmental reaction of potato to the late blight pathogen. -in: Impact on a changing world. Program report. International Potato Center, 1997-98, Lima, Peru, pp. 57-66.

Forman, D. \& Doll, R. (1985): Nitrates, nitrites and gastric cancer in Great Britain. Nature, 313, 620-625.

Friedman, M. \& Levin, C.E. (2009): Analysis and biological activities of potato glycoalkaloids, calystegine alkaloids, phenolic compounds, and anthocyanins.-in: Singh, J. \& KaUR, L. (Eds) Advances in potato chemistry and technology. Elsevier Inc., Burlington, MA, USA, pp. 127-161.

GHolipouri, A.M. \& KANDi, A.S. (2012): Evaluating of nitrogen use efficiency's as affected by different nitrogen fertilizers levels on potato varieties. Adv. Environ. Biol. (AEB), 6, 774-778.

GreEnwood, D.J. \& Hunt, J. (1986): Effect of nitrogen fertiliser on the nitrate contents of field vegetables grown in Britain. J. Sci. Food Agric., 37, 373-383.

HAMOUZ., K., ČEPL, J., VOKÁL, B. \& LACHMAN, J. (1999): Influence of locality and way of cultivation on the nitrate and glycoalkaloid content in potato tubers. Rost. Výroba, 45 (11), 495-501.

Houben, R.J. \& BRunt, K. (1994): Determination of glycoalkaloids in potato tubers by reversed-phase highperformance liquid chromatography J. Chromatogr. A, 661, 169-174.

Hassanpanah, D. (2010): Analysis of GxE interaction by using the additive main effects and multiplicative interaction in potato cultivars. Int. J. Plant Breeding Genetics, 4, $23-29$.

Knuthisen, P., Jensen, U., Schmidt, B. \& Larsen, I.K. (2009): Glycoalkaloids in potatoes: Content of glycoalkaloids in potatoes for consumption. J. Food Compos. Anal., 22, 577-581.

Mensinga, T.T., Speijers, G.J.A. \& Meulenbelt, J. (2003): Health implications of exposure to environmental nitrogenous compounds. Toxicol. Rev., 22, 41-51.

Nema, P.K., Ramayya, N., Duncan, E. \& Niranjan, K. (2008): Potato glycoalkaloids: formation and strategies for mitigation. J. Sci. Food Agric., 88, 1869-1881.

Rao, P. \& Puttanna, K. (2000): Nitrates, agriculture and environment. Curr. Sci. India, 79, 1163-1168.

Tömösközi-Farkas, R., Daood, H.G., Polgár, Zs. \& Hajós, Gy. (2006): Determination of glycoalkaloids in Hungarian potatoes by HPLC. Chromatographia, 63, 115-118. 